\title{
2004 Sosyal Bilgiler 7. Sınıf Öğretim Programı ve Tarih Bilinci *
}

\author{
Zafer ÇAKMAK**, Birol BULUT ***
}

\begin{abstract}
Özet
İnsanları ve yaşamlarını konu alan Sosyal Bilgiler, bireyin kendisini ve diğerlerini daha iyi tanıma ve kişilerin gereksinimleri ile toplumun beklentileri arasındaki dengeyi sağlamada insanlara gerekli bilgi, beceri ve tutumları kazandırma açısından yardımcı olur. Sosyal Bilgilerin, bireyin sosyalleşmesinde yararlandığı ve kendi açısından da vazgeçilmezi olan tarih ise birey ve toplum açısından ayrı bir öneme sahiptir. Çünkü insan; içinde doğduğu toplumun kültürel değerlerini öğrenebilmesi, kendine has beceriler edinebilmesi ve kendi bilincine ulaşmış bir birey haline gelebilmesi, kısacası toplumsallaşabilmesi, ancak toplumu tanımasıyla gerçekleşir ki bu da ancak tarih ile mümkündür. "Tarihin bilincine varmak, insan olmanın ne demek olduğunu anlamakla eş değer" olarak ifade edildiği gibi; yine bireyin dünü anlayıp, bilgi ve deneyimlerin katkısıla bugünü yaşaması ve yarına güvenle hazırlanması, bunun yanı sıra toplumun etkin ve faydalı bir mensubu haline gelmesi, bu bilince varmakla mümkündür. Bu araştırma 7. Sınıf sosyal bilgiler öğretim programında yer alan konuların tarih bilinci oluşturmada etkililiğini, öğretmen görüşleri doğrultusunda ortaya koymayı amaçlamaktadır. Çalışmadan elde edilen sonuç ise 7. Sınıf Sosyal Bilgiler öğretim programında yer alan konuların, mevcut haliyle tarih bilinci oluşturmada önemli ölçüde etkili olduğudur.
\end{abstract}

Anahtar Sözcükler: Sosyal Bilgiler, Tarih, Tarih Bilinci, Tarih Öğretimi.

\section{$20047^{\text {th }}$ Grade Social Studies Curriculum and Historical Consciousness}

\begin{abstract}
Social studies; which takes people and their life as a subject to itself helps to people to recognise theirself and others and also intends to give sufficient information to balance individual needs and social ecpectations. In Social studies history carries a special importance for individual and society in the name of socialization of individual. Because human; must learn values of his/her own social culture, must build his/her own consciousness, in a phrase for socialization of individual and knowing the society history is the only way for it. "Having historical consciousness is equal with knowing what is the being human" which helps to understand yesterday, fulfill today with experiences and being prepared for tomorrow, this is also only way being conscious and being active member of society. This investigation intends to show importance of historical consciousness with blending it with the subjects within social sciences and their teaching among the Social studies of $7^{\text {th }}$ grade. Results we got from the investigation of subjects of $7^{\text {th }}$ grade Social studies curriculum shows that is has great efficiency through historical consciousness with its current status.
\end{abstract}

Key Words: Social Studies History, Historical Consciousness, History Teaching

\footnotetext{
* Bu makale Doç. Dr. Zafer ÇAKMAK'ın danışmanlığında Fırat Üniversitesi Eğitim Bilimleri Enstitüsü’nde Birol BULUT tarafından hazırlanan "ilköğretim 7. Sınıf Sosyal Bilgiler Öğretim Programında Yer Alan Konuların Tarih Bilinci Oluşturmadaki Etkililiğinin Öğretmen Görüşlerine Göre Değerlendirilmesi (Elazığ Ili Örneği)" isimli yüksek lisans tezinin bir bölümünden alınmıştır.

**Doç. Dr., Fırat Üniversitesi, Eğitim Fakültesi, İlköğretim Bölümü, Sosyal Bilgiler Eğitimi Ana Bilim Dalı, Elazığ. E-posta: zcakmak@firat.edu.tr

***Arş. Gör., Fırat Üniversitesi, Eğitim Fakültesi, Illköğretim Bölümü, Sosyal Bilgiler Eğitimi Ana Bilim Dalı, Elazığ.

E-posta: bbulut@firat.edu.tr
} 


\section{Giriş}

Sağlıklı bir hayat ve düşünce tarzının teşekkülünde insanın önce kendini tanıması gerekir. Acaba insanlık hangi geçmişten bu zamana geldi? Hangi fikirler ve idealler nasıl uygulandı ve ne gibi sonuçlar doğurdu? Bu ve buna benzer sorulara cevap vermede öncelikle tarihe müracaat ederiz. Tarih; bir milletin hafızasıdır. Bir fert için hafıza ne ise, meseleyi makro düzeyde ele aldığımız zaman fertlerin oluşturduğu millet için de hafıza yani tarih aynı önemi taşır. (Köstüklü, 1998: 11) Türklerde tarih bilincinin tecessüm etmiş abideleri olan Orhun yazıtları, bu bilincin ilk ürünleridir. Bilge Kağan'ın " Ey Türk Oğuz beyleri, işitin" derken, geçmişte yaşanılan felaketlerle dolu hayatın, gelecekte de yaşanabileceğini hatırlatıyor. "Titre ve kendine dön" ihtarı ile de " geçmiş çağlarda Türk milletini güçlü ve kudretli yapan değerlere bağlan, onları koru, eski hatalarını tekrar işleme" öğüdünü veriyor (Memiş, 1998: 57). Tarih bilinci denilince çoğu zaman haklarında çok fazla bilgi sahibi olmadığımız tarihteki olgu ve olaylardan ibret almak, üstünkörü ders çıkarmak olarak anlaşılmaktadır. Hâlbuki bu sanıldığı kadar kolay bir iş olmayıp tarih bilinci de bundan ibaret değildir. Günümüzde uzman tarihçiler bile ancak ilgilendikleri alandan ibret çıkarabilmektedirler. Öğrencilerden böylesine zor bir işi kolayca başarabileceğini beklemek safdillik olacaktır. Zaten milli tarihin eğitimi, çocukların kişilik kazanması ve milli kimlik şuuruna kavuşması için verilir, tarihçi olması için değil. Öğrenciler, böylece büyük tarihi şahsiyetlerle, gelişim dönemlerinin de bir özelliği olarak, bir duygusal bütünleşmeye ve ortaklaşalık hissine yönelir (Köseoğlu, 2005: 216). Kaldı ki tarih yalnızca ibret değil, kuvvet de verir mensuplarına. Ama bu kuvvet bir yere yönlendirildiği takdirde bir anlama sahip olur. Fazlıoğlu'na göre, tarih ancak geleceğe ilişkin projesi olan milletler için anlam kazanır. Aksi halde hiçbir anlamı yoktur (Fazlıoğlu, 2009: 250-251) Bilinç bu noktada bir anlamlandırma ameliyesidir. Nasıl ki; dili bilinçli kullanmak ne dediğinin farkında olmaksa, tarihi bilinçli yaşamak da ne yaşadığının farkında olmaktır. Bilincin bizatihi kendisinin de değişik tarihsel dönemlerde, değişik kültür ortamlarında değişik kılıklar alabilen bir şey olması hakikaten ilgi çekicidir.

\section{Amaç}

Bu araştırmanın amacl, 2004 İlköğretim 7. Sınıf Sosyal Bilgiler Öğretim Programı'nda yer alan konuların "Tarih Bilinci" oluşturmadaki etkililiğini öğretmen görüşleri doğrultusunda ortaya koymaktır. Bu genel amaca ulaşmak için aşağıdaki sorulara cevap aranmıştır.

a) Sosyal bilgiler öğretmenlerinin program hakkındaki görüşleri cinsiyet, kıdem ve branşa göre değişmekte midir?

b) Illköğretim 7.Sını Sosyal Bilgiler programında yer alan "Iletişim ve İnsan illişkileri", "Ülkemizde Nüfus", "Türk Tarihinde Yolculuk", "Zaman İçinde Bilim", "Ekonomi ve Sosyal Hayat", "Yaşayan Demokrasi", "Ülkeler Arası Köprüler" üniteleri, tarih bilinci oluşturmada etkili midir?

\section{Yöntem}

$\mathrm{Bu}$ bölümde araştırmanın evreni, evrenden alınan örneklem, araştırma grubuna uygulanan anketlerin hazırlanması, verilerin toplanması ile toplanan verilerin işlenmesi ve yorumlanmasında kullanılan istatistiksel yöntemler verilmiştir.

\section{Araştırmanın Yöntemi}

İlköğretim okullarının ikinci kademesinde Sosyal Bilgiler dersi öğretmenlerinin, II. kademe 7. Sınıf Sosyal Bilgiler öğretim programında yer alan tarih konularının tarih bilinci oluşturmadaki etkililiğini öğretmen görüşleri doğrultusunda tespit amacıyla yapılan bu araştırma, tarama modelinde olup, ayrıntılı durum belirlemeye yöneliktir. Araştırma genel tarama modellerinden faydalanılarak gerçekleştirilmiştir. Ankette yer alan ve beşli likerte göre hazırlanmış sorular 7.Sınıf sosyal bilgiler öğretim programında yer alan konuların tarih bilinci oluşturmada etkililiğini öğretmen görüşleriyle ölçme amacıyla hazırlanmış sorulardır.

\section{Evren ve Örneklem}

$\mathrm{Bu}$ araştırmada, ilköğretim okullarının ikinci kademesinde görev yapan sosyal bilgiler dersi öğretmenlerinin, 7. Sınıf Sosyal Bilgiler öğretim programında yer alan konularının tarih bilinci oluşturmadaki etkililiğini ile 
ilgili görüşleri konu alınmaktadır. Elazığ ili ilköğretim kurumlarında görev yapan 147 Sosyal Bilgiler öğretmeni araştırmanın evrenini oluşturmaktadır. Bu araştırmada elde edilen bulgular, 2010-2011 öğretim yılında Elazığ ili merkezindeki ilköğretim okullarında görev yapan sosyal bilgiler öğretmenlerinin anket sorularına verdikleri yanıtlar ve ilgili literatürle sınırlıdır. Araştırmanın örneklemi Elazığ il merkezine bağlı okullardan 145 Sosyal Bilgiler öğretmenini kapsamaktadır.

\section{Bulgu ve Yorumlar}

Bu bölümde 7.Sınıf Sosyal Bilgiler öğretim programında yer alan konuların tarih bilinci oluşturmada etkililiği hakkında öğretmen görüşlerine yönelik bulgulara ve yorumlara yer verilmiştir. Sosyal bilgiler dersi öğretmenlerinin 7.Sınıf Sosyal Bilgiler öğretim programında yer alan konuların tarih bilinci oluşturmada etkililiği ile ilgili görüşleri; genel inceleme ve sonuçları ile anketteki sorulara verilen cevaplardan elde edilen genel sonuçlar aşağıda açıklanmıştır. Ayrıca sonuçların sayısal verileri tabloda gösterilmiştir.

Araştırmaya katılan Sosyal Bilgiler öğretmenlerinin cinsiyetleri, meslek kıdemleri, mezun oldukları bölüm veya ana bilim dalı değişkenlerine ilişkin veriler incelendiğinde, cinsiyet değiş̧keni açısından araştırmaya katılan Sosyal Bilgileröğretmenlerinin $\% 65$ 'inin erkek, \% 35'inin kadın olduğu görülmektedir. $\mathrm{Bu}$ veriler erkekler ve kadınlar arasındaki araştırmaya katılım oranının erkeklerde biraz daha fazla olduğunu göstermektedir. Meslekî kıdem değişkeni açısından araştırmaya katılan öğretmenlerin \% 31'i 0-5 yıldır Sosyal Bilgiler öğretmeni olarak görev yapan kişilerden oluştuğu, \% 23'nün 6-10 yıl arası bir süredir; $\%$ 21'inin 11-15 yıl arası bir süredir; \% 21'inin 16-20 yıl arası bir süredir; \% 4'ünün 21 ve üzeri bir süredir Sosyal Bilgiler öğretmeni olarak görev yaptıkları görülmektedir. Örneklemdeki Sosyal Bilgiler öğretmenlerinin \% 75'inin 0-15 yıl arası bir süredir Sosyal Bilgiler öğretmeni olarak görev yapıyor olmaları, araştırmanın genç ve dinamik sayılabilecek bir öğretmen grubundan alınan veriler çerçevesinde yürütüldüğünü göstermesi açısından önem arz etmektedir.

Araştırmaya katılan öğretmenlerin, \% 70'inin Eğitim Fakültelerinin Sosyal Bilgiler Eğitimi Anabilim Dalı'ndan; \% 25'nin Fen-
Edebiyat Fakültelerinin Tarih Bölümü'nden mezun olduklarl; \% 5 'inin ise Fen-Edebiyat Fakültesinin (İnsani ve Sosyal Bilimler Fakültesinin) Coğrafya Bölümünden mezun oldukları görülmektedir. Örneklem grubunun \% 70'inin Sosyal Bilgiler öğretmenliği mezunu kişilerden oluşması, dikkate değer bir veri olarak göze çarpmaktadır.

Tablo 2' da yer alan maddelerin ortalaması $(\bar{X}=3.92)^{\prime}$ dir. Bu sonuç ile 7.sınıf Sosyal Bilgiler öğretim programında yer alan konuların tarih bilinci oluşturmada etkili olduğu, Sosyal bilgiler öğretmenleri tarafından ifade edilmiştir. 25 maddeye bakıldığında; 9 maddeye kesinlikle katıliyorum, 10 maddeye katılıyorum, 1 maddeye kararsızım yanıtı verildiği görülmektedir. Öğretmenlerin verdiği yanıtta en yüksek ortalama ile 7. Maddedeki, "'Türk Tarihinde Yolculuk' ünitesinde, Fatih'in ve Kanuni'nin fetihlerinin, Barbaros, Piri Reis, Sokullu gibi önemli devlet adamlarının tanıtılması tarih bilinci oluşturmada etkilidir" ifadesi olup, $(\bar{X}=4,47)$ ortalamayla kesinlikle katılıyorum sonucunu vermiştir. Bu maddenin en yüksek ortalamayı alması, öğrencilerin tarihi şahsiyetlerle yakınlık kurması ve kendisine heyecan verenlerle özdeşleşmeye çalışması bireyin kişiliğinde önemli katkılar sağlayacağı, sosyal bilgiler öğretmenleri tarafından da desteklenmiş oluyordu. Bu maddeyi "Türk Tarihinde Yolculuk' ünitesinde Toplumsal Hoşgörü ve Etkileşim konusunda azınlıklara ve farklı din mensuplarına Osmanlı Devletince gösterilen hoşgörü ve toleransın örneklenmesi Sosyal Bilgiler öğretiminin hedefleri ile tutarlıdır" maddesi $(\overline{\mathrm{X}}=4,46)$ izlemektedir. Bu maddenin ikinci yüksek ortalamayı alması; Osmanlı döneminde diğer etnik unsurlara gösterilen hoşgörü ve toleransın, Sosyal Bilgiler hedefleri açısından son derece iyi bir örnek oluşturmasından kaynaklandığı kanaatindeyim. Sosyal Bilgiler öğretiminin evrensel amaçları kapsamında yer alan, sosyal katılıma ilişkin amaçlar kısmındaki "farklı inanç ve kültürlere ve ihtiyaçlara, duygulara, sorunlara, başkalarının hedeflerine, birey ve gurupların sorumluluklarına, hak ve özgürlüklerin çiğnenmesine karşı sorumluluk gösterme; basmakalıp düşünceleri, ön yargıları ve bağnazlığı ortadan kaldırmanın gerekliliğine karşı hassas olma" maddesine iyi bir örnek teşkil etmektedir (Öztürk, 2009: 10). $\mathrm{Bu}$ da Sosyal Bilgiler öğretiminin hedeflerine ulaşıımasında kolaylık sağlayacaktır. 
Tablo: 1. Sosyal Bilgiler 7.Sınıf Öğretim Programında Yer Alan Konuların Tarih Bilinci Oluşturmada ki Etkiliği Hakkındaki Öğretmenlerin Görüşlerinin Frekans ve Yüzdeleri

\begin{tabular}{|c|c|c|c|}
\hline & Maddeler & $\bar{X}$ & SS \\
\hline $1-$ & $\begin{array}{l}\text { "Illetişim ve İnsan İlişkileri” ünitesinde yer alan Atatürk'ün iletişime } \\
\text { verdiği önemi belirten ifadeler, kurdurduğu gazeteler ve Anadolu } \\
\text { Ajansı'nın tarihini anlatan konular tarih bilincine katkıda bulunur. }\end{array}$ & 4,14 & 827 \\
\hline $2-$ & $\begin{array}{l}\text { "Illetişim ve insan ilişkileri” ünitesinin kapsamındaki konuların } \\
\text { işlenişinde (özellikle drama tekniğinin kullanılmaması) önemli } \\
\text { tarihsel kişiliklerin iletişim örneklerinin Öğretmen Kılavuz } \\
\text { Kitabınızda ve ders kitaplarında yer almaması önemli bir eksikliktir. }\end{array}$ & 2,15 & ,960 \\
\hline $3-$ & $\begin{array}{l}\text { "Ülkemizde Nüfus" ünitesinde geçen "Göç" olgusunun sebep ve } \\
\text { sonuçları aktarılırken, ülkemiz tarihinin son } 200 \text { yılına şekil veren } \\
\text { göç olaylarına yer verilmemesi büyük bir eksikliktir. }\end{array}$ & 2,19 & 1,085 \\
\hline $4-$ & $\begin{array}{l}\text { "Türk Tarihinde Yolculuk" ünitesinde Anadolu'da kurulan ilk Türk } \\
\text { beylikleri hakkında sınırlı bir siyasi bilgi verilmesi, Selçuklu sonrası } \\
\text { kurulan Türk beylikleri hakkında hiç bilgi verilmemesi tarihi idrakte } \\
\text { noksanlıklara yol açar. }\end{array}$ & 1,86 & 1,60 \\
\hline $5-$ & $\begin{array}{l}\text { "Türk Tarihinde Yolculuk" ünitesinde Osmanlı devlet ve toplum } \\
\text { yapısıyla ilgili açıklama ve grafikler tarihi bilinç oluşturmaya zemin } \\
\text { hazırlar. }\end{array}$ & 4,10 & 900 \\
\hline 6- & $\begin{array}{l}\text { Türk Tarihinde Yolculuk" ünitesinin kazanımlarında (hedef } \\
\text { davranışlar) duyuşsal alana ait (ilgi, tutum) herhangi bir hedefe yer } \\
\text { verilmemesi, tarih bilincinin oluşmasını baştan engeller. }\end{array}$ & 2,26 & 955 \\
\hline 7- & $\begin{array}{l}\text { "Türk Tarihinde Yolculuk" ünitesinde, Fatih'in ve Kanuni'nin } \\
\text { fetihlerinin, Barbaros, Piri Reis, Sokullu gibi önemli devlet } \\
\text { adamlarının tanıtılması, tarih bilinci oluşturmada etkilidir. }\end{array}$ & 4,47 & 704 \\
\hline 8- & $\begin{array}{l}\text { "Türk Tarihinde Yolculuk" ünitesinde Toplumsal Hoşgörü ve } \\
\text { Etkileşim konusunda azınlıklara ve farklı din mensuplarına Osmanlı } \\
\text { Devletince gösterilen hoşgörü ve toleransın örneklenmesi Sosyal } \\
\text { Bilgiler öğretiminin hedefleri ile tutarlıdır. }\end{array}$ & 4,46 & 743 \\
\hline 9- & $\begin{array}{l}\text { "Türk Tarihinde Yolculuk" ünitesinde kültürel ve toplumsal sahada } \\
\text { Osmanlı-Avrupa karşııılı etkileşiminin; müzikten kılık kıyafete, } \\
\text { estetikten mimariye olan tesirlerinin izahı öğrencide tarih bilinci } \\
\text { oluşturmada etkilidir. }\end{array}$ & 4,04 & 958 \\
\hline $10-$ & $\begin{array}{l}\text { "Türk Tarihinde Yolculuk" ünitesinde "Seyyahlarla Gezinti" konu } \\
\text { başlığında yabancı seyyahların gözüyle Osmanlı ve Türk toplum } \\
\text { hayatından kesitler sunulması, öğrencilerde tarihsel bir derinlik ve } \\
\text { devamlılık duygusu oluşturmada etkilidir. }\end{array}$ & 4,20 & ,827 \\
\hline $11-$ & $\begin{array}{l}\text { "Türk Tarihinde Yolculuk", ünitesinde yer alan "Osmanlıda } \\
\text { Yenileşme" konusu işlenirken 7.ve 18. yy. da Osmanlı yenilik } \\
\text { hareketlerinin (matbaanın, yeni eğitim kurumlarının, bankaların } \\
\text { kurulması) sebep ve neticelerinin verilmesi eleştirel bir tarih bilincinin } \\
\text { oluşumuna katkı sağlar. }\end{array}$ & 3,99 & ,933 \\
\hline $12-$ & $\begin{array}{l}\text { "Türk Tarihinde Yolculuk" ünitesinde geçen konular tarih bilinci } \\
\text { oluşturmada genel olarak yeterli ve etkilidir. }\end{array}$ & 3,20 & 1,21 \\
\hline $13-$ & $\begin{array}{l}\text { "Türk Tarihinde Yolculuk" ünitesinde yer alan kavramlar ve değerler } \\
\text { (yurt, millet, Anadolu, Türk, Türkleşme) öğrencide tarih bilincinin } \\
\text { oluşumunda önemli rol oynar. }\end{array}$ & 3,88 & 933 \\
\hline
\end{tabular}




\begin{tabular}{|c|c|c|c|}
\hline 14- & $\begin{array}{l}\text { "TürkTarihinde Yolculuk" ünitesinde doğrudan verilecek beceriolan } \\
\text { zaman ve kronoloji algılama, estetik tarih bilincinin oluşmasında } \\
\text { gerekli temeli sağlar. }\end{array}$ & 3,56 & 1,10 \\
\hline $15-$ & $\begin{array}{l}\text { "Zaman İ̧̧inde Bilim" ünitesinde insan yaşamını kolaylaştıran } \\
\text { önemli buluşların, çeşitli milletlerin katkılarıyla belli bir etkileşim } \\
\text { ve süreklilikle meydana geldiğinin işlenmesi ve yazının önemi } \\
\text { üzerinde durulması, tarih bilincinin evrensel yönünün oluşumuna } \\
\text { katkıda bulunur. }\end{array}$ & 4,20 & 806, \\
\hline 16- & $\begin{array}{l}\text { "Zaman İçinde Bilim" ünitesinde Coğrafi Keşifler, Rönesans, Reform, } \\
\text { Aydınlanma Çağı ve bilim arasındaki sebep-sonuç ilişkilerinin ortaya } \\
\text { konması, bilimin dayandığı tarihsel temellerin anlaşılmasında ve } \\
\text { idrakinde önem taşır. }\end{array}$ & 4,21 & 846, \\
\hline 17- & $\begin{array}{l}\text { "Zaman İçinde Bilim" ünitesi "Tarihte Bilim" konu başığı altında } \\
\text { bilime katkı sağlayan İbn-i Sina, Biruni, Ali Kuşçu gibi Türk-İslam } \\
\text { âlimlerinin tanıtılması öğrencilerde tarih bilinci oluşmasına önemli } \\
\text { bir katkı sağlar. }\end{array}$ & 4,37 & 723 \\
\hline 18- & $\begin{array}{l}\text { "Ekonomi ve Sosyal Hayat" ünitesinde yer alan konularda tarihten } \\
\text { ve günümüzden örnekler verilerek üretim teknolojisindeki } \\
\text { gelişmelerin sosyal ve ekonomik hayattaki etkilerinden bahsetmesi } \\
\text { geçmişle günümüzün kıyaslamasına yardımcı olur. }\end{array}$ & 4,18 & 712 \\
\hline 19- & $\begin{array}{l}\text { "Ekonomi ve Sosyal Hayat" ünitesinde yer alan konularda toprağın } \\
\text { bir milleti millet yapma rolünü, vatan kavramının toprakla mümkün } \\
\text { olabileceğinin vurgulanması bireyin tarihsel düşüncesinin } \\
\text { gelişmesine katkıda bulunur. }\end{array}$ & 4,11 & 957, \\
\hline $20-$ & $\begin{array}{l}\text { "Ekonomi ve Sosyal Hayat" ünitesinde yer alan "Türklerde Vakıf } \\
\text { Kültürü" adlı konuda vakıfların çalışmalarına ve sosyal yaşamdaki } \\
\text { rolüne tarihten ve günümüzden örnekler vererek öğrencilerde } \\
\text { tarihsel bilincin gelişmesine katkıda bulunur }\end{array}$ & 4,09 & 909 \\
\hline 21- & $\begin{array}{l}\text { "Ekonomi ve Sosyal Hayat" ünitesinde yer alan " geçmişte ve } \\
\text { günümüzde mesleki eğitim " adlı konuda ahi teşkilatının işlenişi } \\
\text { öğrencilerde meslek ve meslek ahlakının gelişmesini sağlar. }\end{array}$ & 4,31 & 814 \\
\hline $22-$ & $\begin{array}{l}\text { "Yaşayan Demokrasi" ünitesinde geçmişten günümüze yönetim } \\
\text { ve demokrasi anlayışıyla ilgili verilen bilgiler, öğrencinin tarihsel } \\
\text { süreçte yaşanan değişiklikleri ve günümüzdeki yapıyı daha kolay } \\
\text { anlamasını sağlar. }\end{array}$ & 4,31 & 758, \\
\hline 23- & $\begin{array}{l}\text { "Yaşayan Demokrasi" ünitesinde yer alan Türkiye Cumhuriyet'inde } \\
\text { devletin yönetim yapısı, yasa ve kurum ile ilgili bilgiler bireyin } \\
\text { ülkesini tanımasına yardımcı olur. }\end{array}$ & 4,08 & 857 \\
\hline 24- & $\begin{array}{l}\text { "Ülkeler Arası Köprüler" adlı ünitede yer alan "1.Dünya Savaşı ve } \\
\text { Çanakkale'de Mustafa Kemal" konusunda, öğrencilere "bağımsızlık, } \\
\text { Milli kültür, ortak miras" gibi kavramlar oğrencilerin tarihsel } \\
\text { düşüncesinin gelişiminde katkı sağlar. }\end{array}$ & 4,13 & 855 \\
\hline & Genel & 3,92 & \\
\hline
\end{tabular}


En düşük ortalama ise 4. Maddedeki; "Türk Tarihinde Yolculuk' ünitesinde Anadolu'da kurulan ilk Türk beylikleri hakkında sınırlı bir siyasi bilgi verilmesi, Selçuklu sonrası kurulan Türk beylikleri hakkında hiç bilgi verilmemesi tarihi idrakte noksanlara yol açar" ifadesi olup, $(\bar{X}=1,86)$ ortalamayla katılmıyorum sonucunu vermiştir. Bu maddeyi ( $\overline{\mathrm{X}}=2,15)$ ortalamayla 2. Madde olan "iletişim ve insan ilişkileri' ünitesinin kapsamındaki konuların işlenişinde (özellikle drama tekniğinin kullanılmaması) önemli tarihsel kişiliklerin iletişim örneklerinin Ögrretmen Kılavuz Kitabınızda ve ders kitaplarında yer almaması önemli bir eksikliktir" fadesiyle Katılmıyorum sonucunu vermiştir.

Diğer maddeler ise genel anlamda incelendiğinde 1. Madde $(\overline{\mathrm{X}}=4,14)$ ortalamayla "iletişim ve Insan ilişsileri' ünitesinde yer alan Atatürk'ün iletişime verdiği önemi belirten ifadeler, kurdurduğu gazeteler ve Anadolu Ajansı'nın tarihini anlatan konular tarih bilincine katkıda bulunur" ifadesi olup Kesinlikle Katılıyorum sonucunu vermiştir. 3. Madde $(\bar{X}=2,19)$ ortalamayla "Ülkemizde Nüfus' ünitesinde geçen 'Göç' olgusunun sebep ve sonuçları aktarılırken ülkemiz tarihinin son 200 yılına şekil veren göç olaylarına yer verilmemesi büyük bir eksikliktir" ifadesi olup katılmıyorum sonucunu vermiştir. 5. Madde $(\bar{X}=4,10)$ ortalamayla "Türk Tarihinde Yolculuk' Ünitesinde Osmanlı devlet ve toplum yapısıyla ilgili açıklama ve grafikler tarihi bilinç oluşturmaya zemin hazırlar" ifadesi olup katılıyorum sonucunu vermiştir. 6. Madde $(\bar{X}=2,26) \quad$ ortalamayla "'Türk Tarihinde Yolculuk' Ünitesinin kazanımlarında (hedef davranışlar) duyuşsal alana ait (ilgi, tutum) herhangi bir hedefe yer verilmemesi tarih bilincinin oluşmasını baştan engelleyicidir" ifadesi olup katılmıyorum sonucunu vermiştir. 9. Madde $(\bar{X}=4,04)$ ortalamayla "Türk Tarihinde Yolculuk' ünitesinde kültürel ve toplumsal sahada Osmanlı-Avrupa karşılıklı etkileşiminin; müzikten kılık klyafete, estetikten mimariye olan tesirlerinin izahı ögrencide tarih bilinci oluşturmada etkilidir" ifadesi olup katılıyorum sonucunu vermiştir. 10. Madde $(\bar{X}=4,20)$ ortalamayla "Türk Tarihinde Yolculuk' ünitesinde "Seyyahlarla Gezinti" konu başlığında yabancı seyyahların gözüyle Osmanlı ve Türk toplum hayatından kesitler sunulması, öğrencilerde tarihsel bir derinlik ve devamlılık duygusu oluşturmada etkilidir" ifadesiyle kesinlikle katılıyorum sonucunu vermektedir. 11. Madde $(\bar{X}=3,99)$ ortalamayla "Türk Tarihinde Yolculuk" "Osmanlıda Yenileşme' konusunda yer alan 17.ve 18.yy da Osmanlı yenilik hareketlerinin (matbaanın, yeni eğitim kurumlarının, bankaların kurulması) sebep ve neticeleri eleştirel bir tarih bilincinin oluşumuna katkı sağlar"i ifadesi olup Katılıyorum sonucunu vermiştir. Bu maddede, bahse konu olan 17. ve 18.yy Osmanlı döneminde yapılan yeniliklerinin ne derece etkili olduğunun bireyler tarafından sorgulanması ve bu konu hakkında düşünülmesi, bireyin eleştirel bir yaklaşımla konulara yaklaşmasını kolaylaştıracaktır. Bu da bireyin tarihi olaylara tek tarafı bakmasından ziyade, bir tarih bilinci ile olayları çok yönlü incelemesi, sebep ve sonuç çerçevesinde özgün bir değerlendirme yapmasını sağlayacaktır. 12 . Madde $(\overline{\mathrm{X}}=3,20)$ ortalamayla "TürkTarihindeYolculuk'ünitesinde geçen konular tarih bilinci oluşturmada genel olarak yeterli ve etkilidir" ifadesi olup, bu ünitenin tarih bilinci oluşturmadaki etkililiğine ve yeterliliğine bütünsel bakılmış ve öğretmenlerden elde edilen veriler neticesinde Kararsızım sonucu ortaya çıkmıştır. 13. Madde $(\bar{X}=3,88) \quad$ ortalamayla "'Türk Tarihinde Yolculuk' ünitesinde yer alan kavramlar ve değerler (yurt, millet, Anadolu, Türk, Türkleşme) öğrencide tarih bilincinin oluşmasında önemli rol oynar" ifadesi olup katılıyorum sonucunu vermiştir. 14. Madde $(\bar{X}=3,56)$ ortalamayla "Türk Tarihinde Yolculuk" ünitesinde doğrudan verilecek beceri ve değer olan zaman ve kronoloji algılama, estetik tarih bilincinin oluşmasında gerekli temeli sağlar ifadesi olup katılıyorum sonucunu vermiştir. 15. Madde $(\bar{X}=4,20)$ ortalamayla "Zaman Içinde Bilim' ünitesinde insan yaşamını kolaylaştıran önemli buluşların, çeşitli milletlerin katkılarıla belli bir etkileşim ve süreklilikle meydana geldiğinin işlenmesi ve yazının önemi üzerinde durulması tarih bilincinin evrensel yönünün oluşumuna katkıda bulunur" ifadesiyle tarih bilincinin evrensel yönü vurgulanmış ve bu madde de yer alan ifadenin doğrululuğu öğretmenler tarafından da kabul görmüştür. Öğretmenlerden elde edilen veriler neticesinde kesinlikle katılıyorum sonucu ortaya çıkmıştır. 16 . Madde ( $\bar{X}=4,21)$ ortalamayla "'Zaman İçinde Bilim' ünitesinde Coğrafi Keşifler, Rönesans, Reform, Aydınlanma Çağı ve bilim arasındaki sebep-sonuçilişkilerinin ortaya konması bilimin dayandığı tarihsel temellerin anlaşılmasında ve idrakinde önem 
taşır" ifadesi olup Kesinlikle katılıyorum sonucunu vermiştir. 17. Madde $(\overline{\mathrm{X}}=4,37)$ ortalamayla "Zaman İçinde Bilim' ünitesi 'Tarihte Bilim' konu başlığı altında bilime katkı sağlayan Ibn-i Sina, Biruni, Ali Kuş̧̧u gibi Türkİslam âlimlerinin tanıtılması öğrencilerde tarih bilinci oluşmasına önemli bir katkı sağlar" ifadesi ile öğretmenlerden elde edilen veriler kesinlikle katılıyorum sonucunu ortaya çıkarmıştır. 18. Madde $(\bar{X}=4,18)$ ortalamayla "Ekonomi ve Sosyal Hayat' ünitesinde yer alan konuların tarihten ve günümüzden örnekler vererek üretim teknolojisindeki gelişmelerin sosyal ve ekonomik hayata etkilerinin geçmişle günümüz arasında kıyaslamasına yardıma olur" ifadesi olup, bu maddeyle tarih bilincinin sadece geçmişle ilgili olmayıp, günümüzü de kapsadığı ve geçmişi, o dönemin şartlarıyla yorumlamanın yanı sıra günümüz bakış açısıyla da değerlendirmemizi sağlaması açısından dikkat çekicidir. Öğretmenlerden elde edilen verilerle katılıyorum sonucu ortaya çıkmıştır. 19. Madde $(\bar{X}=4,11)$ ortalamayla "Ekonomi ve Sosyal Hayat' ünitesinde yer alan konularda toprağın bir milleti millet yapma rolünü, vatan kavramının toprakla mümkün olabileceğini vurgulanması bireyin tarihsel düşüncesinin gelişmesine katkıda bulunur" ifadesiyle vatan ve millet değerlerinin bireyde oluşmasına katkı sağlayan bir konu olduğu öğretmenler tarafından da kabul görmüş ve elde edilen veriler neticesinde Katılıyorum sonucu ortaya çıkmıştır. 20. Madde $(\overline{\mathrm{X}}=4,09)$ ortalamayla "Ekonomi ve Sosyal Hayat' ünitesinde yer alan 'Türklerde Vakıf Kültürü' adlı konuda vakıfların çalışmalarına ve sosyalyaşamdakirolünetarihtenvegünümüzden örnekler vererek ögrrencilerde tarihsel bilincin gelişmesine katkıda bulunur" ifadesi olup, elde edilen verilerle katılıyorum sonucu ortaya çıkmıştır. 21. Madde $(\bar{X}=4,31)$ ortalamayla "Ekonomi ve Sosyal Hayat' ünitesinde yer alan 'Geçmişte ve Günümüzde Mesleki Eğitim' adlı konuda ahi teşkilatının işlenişi öğrencilerde meslek ve meslek ahlakının gelişmesini sağlar" ifadesi kesinlikle katılıyorum sonucunu ortaya çıkarmıştır. 22. Madde ( $\overline{\mathrm{X}}=4,31)$ ortalamayla "Yaşayan Demokrasi' ünitesinde geçmişten günümüze yönetim ve demokrasi anlayışıla ilgili verilen bilgiler öğrencinin tarihsel süreçte yaşanan değişiklikleri ve günümüzdeki yapıyı daha kolay anlamasını sağlar" ifadesi olup kesinlikle katılıyorum sonucunu ortaya çıkarmıştır. 23. Madde $\left(\bar{X}_{=} 4,08\right)$ ortalamayla
"Yaşayan Demokrasi' ünitesinde yer alan Türkiye Cumhuriyet'inde devletin yönetim yapısı, yasa ve kurum ile ilgili bilgiler bireyin ülkeyi tanımasına yardımcı olur" ifadesi olup katıliyorum sonucunu vermiştir. 24. Madde $(\bar{X}=4,13)$ ortalamayla "Ülkeler Arası Köprüler" adlı ünitede yer alan "1.Dünya Savaşı ve Çanakkale'de Mustafa Kemal' konusunda öğrencilere 'bağımsızlık, Milli kültür, ortak miras' gibi kavramlar tarihsel düşüncesinin gelişmesine katkı sağlar" ifadesi olup, kavramsal çerçevede tarih bilincinin gelişmesine katkıda bulunur. $\mathrm{Bu}$ maddeye ilişkin olarak öğretmenlerden elde edilen veriler neticesinde katılıyorum sonucu ortaya çıkmıştır.

\section{Tartışma}

Insan sosyal bir varlıktır. Bu nedenle çevresiyle birlikte yaşamak durumunda olan insanın, sağlıklı bir hayat veya düşünce yapısına sahip olabilmesi için önce kendini, sonra da mensubu olduğu toplumu tanıması gerekir. İnsanlığın bir parçası olduğu bilincini taşıyarak, ülkesini ve dünyayı ilgilendiren konulara duyarlılık gösteren ve etkili vatandaşlık bilincine ulaşmış insan modeli oluşturmada büyük rolü bulunan Sosyal Bilgiler, bireyin sosyal ve fiziki çevresiyle etkileşiminin ve bu etkileşimin dünkü, bugünkü ve yarınki biçimlerinin gözden geçirilmesini sağlar. Sosyal Bilgiler dersi, toplumların geçmiş, günümüz ve gelecekteki politik, ekonomik, kültürel ve çevresel sorunlarını ve bunların çözümüne yönelik eğitimi ön plana alır. Sosyal Bilgiler öğretimi, günümüzdeki sorunların kökenlerinde yer alan faktörlerin tarihsel boyutunu gösterip, geleceği daha iyi planlamaya olanak verir (Polat, 2006: 14-15).

Sosyal Bilgilerin temel aldığı en önemli disiplinlerden birisi "tarih"tir. Toplumu ilgilendiren her konuda "tarih" disiplini karşımıza çıkmaktadır. Bugünün inşasında önemli rol oynayan ve insanları geleceğe hazırlayan Tarih bilimi, sadece geçmiş hakkında bilgi alma ve haberdar etmekten ibaret değildir. Tarih, yalnızca önceden olmuş hadiseler değildir. Tarih, bir asırdaki bağımsız kültürlerin, bağımsız medeniyetlerin, bağımsız toplumların, belirli kavimlerin ve ırkların incelenmesi de değildir. Tarih, şimdiki zamanı ortaya çıkarmış olan bir geçmiştir. Tarih, geleceğe dönük olan bir hareket olup, insanlığın ortak ürünüdür (Biçer, 2008: 10). Öztürk : 
“Biz geçmişi geçmişte kaldı zannediyoruz ama yanılıyoruz. Hâlbuki geçmiş içinde yaşadığımız anı da kapsamaktadır. Bu haliyle tarih sadece geçmişte kalan bir vakıa değil, ördüğümüz canlı ve dinamik bir vakıadır. Tarihselliğin bir gereği olarak, geçmişimizi yaşıyoruz. İstesek de istemesek de, kabul etsek de kabul etmesek de..." diye yorumlar. (Öztürk, 2010: 72-94)

Tarih, bugünü ve geleceği anlamamı için elimizdeki tek anahtardır. Ne halde olduğumuzu bilebilmek için, geçmişte ne olduğumuzu bilmemiz gerekir ki, bu da ancak tarih ile mümkündür (Sander, 2010: 28). Hegel, tarihsel bilgi için "şimdi - geçmiş ilişkisi" olduğunu kavrar. Tarih, onun için "geçmişin sürekli etkinliği" olarak bugünü var eder ve bu da, 'gelenek'in şimdi için anlam kaynağı olmayı sürekli olarak sürdürmesi ile eştir (Özlem ve Ateşoğlu, 2006: 21). Tarih zamanların ışığı, olayların hazinesi, gerçeğin sadık şahidi, iyi öğütlerin ve tedbirlerin kaynağı, davranışların ve adetlerin kaidesi olarak değerlendiren Montesquieu, tarihin faydasını da şöyle özetliyor; " Eğer tarihe yabancı olursak, bizden önce gelenlere ve bizi çevreleyen her şeye karşı derin bir cehalet içinde kalırdık; tarih öyle bir anahtardır ki bütün ülkelerin ve çağların kapılarını açar." Evet tarih, geçmişi anlayıp, bugünü yaşamak ve geleceğe hazırlanmak için elimizdeki tek anahtardır (Niyazi, 2009: 23).

Tarihin bilincine varmak, insan olmanın ne demek olduğunu anlamakla eş değerdedir. (Bıçak, 1996: 51) Tarih hafızası ve bilinci zayıf olan bir toplumun tarihe kendi varoluş çizgisini ve damgasını vurabilmesi çok güçtür. Tarihi akışı belirleme konusunda iddialı ve etken toplumlarla tarihi akış tarafından belirlenen iddiasız ve edilgen toplumlar arasındaki en önemli fark da tarihi algılayış biçimleridir. Yani tarihi algılayış biçimlerine göre birey veya toplumların etken veya edilgen olma rolleri ortaya çıkıyor (Davutoğlu, 2011:60).

Tarih bilinci, yaşanılan anın, bireyin veya toplumun omuzlarına, dahası ruhuna yığıp yüklediği bir takım gereksiz ağırlıkları kaldırır, bireyi ve toplumu ruh sağlığına kavuşturur, onlara, gücünü tarihin derinliklerinden alan yeni hamlelere hazırlar. Baltacıoğlu, 1914 tarihli bir yazısında şöyle der;
Biz, elsiz, kolsuz, bacaksız, kalpsiz, kansız, cansız millet, biz bayrak sevmeyen, geçmişine, dedelerinin mezarlarına hürmet etmeyen, camilerin avlularına pisleyen, çeşmelerin yalaklarını süprüntü ile dolduran biz, elifbadan, kıraattan, hesaptan evvel kanda, canda, ruhta inkılaplara muhtaç bir milletiz. Biz, eğer yaşamak istiyorsak, çürüyen ciğerlerimizi, kamburlaşan vücudumuzu, körleşen zekâmızı, sönen kalbimizi kuvvetle, imanla dolduralım. (Akyüz, 2001: 287)

Baltacıoğlu'nun bu yazısında bahsettiği husus bizce tarih öğretimi ile mümkündür. Canda, kanda, ruhta inkılâp yapmak ancak tarih bilincine varmakla gerçekleşir.

Tarihi, çocuklarımızın kişilik kazanması ve milli kimlik şuuruna kavuşması için verilir. Dilek (2002:33-34)'e göre tarih öğretimi, öğrencinin kişisel gelişiminde bir öğe olarak kabul edilir. Bir sosyalleşme aracı olarak kültürel mirasın aktarıcısıdır. Birey ve millet açısından geleceği inşa etmede hazır tecrübeleri sunan önemli bir unsurdur. Ayrıca tarih öğretimi, vatandaşlık eğitiminde de bir araç olarak kullanılır. Tarih öğretiminin; kültürel mirasımızın önemli bir parçası olması, karşılaştırma, çözümleme, sentez ve öteleme gibi eğitimsel becerileri geliştirmesi, her öğrencinin bilmesi gereken fikir ve kavramları vermesi, geniş bir literatürü içermesi, dünya vatandaşlığı için eğitimde önemli bir unsur olması, okul hayatına katkıda bulunması, yaşama uyum sağlamada öğrencilere yardımcı olması, empatiyi beslemesi, öğrencileri iyi birer vatandaş ve milletin sadık taraftarları yapması, toplumu kaynaştırması bakımından önemli ve gerekli olduğu belirtilmelidir. (Işık, 2008: 18).

\section{Sonuç ve Öneriler}

7. Sınıf Sosyal Bilgiler öğretim programında yer alan konuların tarih bilinci oluşturmada etkililiğini ölçmek için oluşturulan ve Tablo: 2 de betimsel olarak ortaya konan maddelerin öğretmenlerden elde edilen verilerine göre ortalaması ( $\overline{\mathrm{X}}=3.92)^{\prime}$ 'dir. Bu sonuç ile 7.sınıf Sosyal Bilgiler öğretim programında yer alan konuların tarih bilinci oluşturmada etkili olduğu Sosyal Bilgiler öğretmenleri tarafından ifade edilmiştir. Sosyal Bilgiler öğretmenlerinin, 7. Sınıf Sosyal Bilgiler 
programında yer alan konuların tarih bilinci oluşturmada etkililiği ile ilgili görüşlerinin; cinsiyet ve kıdemlerine göre aralarında anlamsal bir farklılık olmadığı görülmektedir. Fakat öğretmenlerin, programın tarih bilinci oluşturmada etkililiği ile ilgili görüşleri, branşlar arasında anlamsal bir farklılığı ortaya çıkarmıştır. Sosyal Bilgiler öğretmenlerinin 7. Sınıf Sosyal Bilgiler programında yer alan konuların tarih bilinci oluşturmada etkililiği ile ilgili ortalaması ( $\overline{\mathrm{X}}=114,02)$ çıkmıştır. Tarih öğretmenlerinin görüşleri doğrultusunda elde edilen verilerin ortalaması $(\bar{X}=112,34)$ çıkmış iken coğrafya öğretmenlerinin görüşleri doğrultusunda elde edilen verilerin ortalaması $(\bar{X}=117,86)^{\prime}$ dır. Bu durumda, Coğrafya öğretmenlerinin görüşlerinden elde edilen verilerin analizi sonucu ortaya çıkan ortalamanın, Sosyal Bilgiler ve tarih öğretmenlerine oranla anlamlı bir biçimde yüksek olduğu görülmektedir. Bu bulgu, her ne kadar araştırmaya katılan tüm öğretmenlerin, bu programda yer alan konuların tarih bilinci oluşturmada etkililiği ile ilgili görüşlerini "orta" düzeyde olduğunu gösterse bile, branşı coğrafya olan öğretmenlerden elde edilen veriler, programın tarih bilinci oluşturmada diğer öğretmenlere kıyasla daha etkili olduğu sonucu ortaya çıkarmıştır. Branşı coğrafya olan öğretmenlerden sonra en yüksek değer Sosyal Bilgiler mezunu öğretmenlere aittir. Diğer branşlara kıyasla en düşük değeri alan bölüm ise tarihtir.

Toplumun sağlıklı adımlar atabilmesi ve her bireyi mutlu kılacak kuralların uygulanabilmesinde eğitimin rolü büyüktür. Eğitim, toplumların bilinçlenmesinde önemli bir unsur olarak görülmüş ve özellikle tarih eğitimi bu konuda öncü bir rol oynamıştır (Şengül, 2007: 67) Atatürk, "Tarih bir milletin nelere müsait olduğunu ve neler başarmaya muktedir bulunduğunu gösteren en doğru bir kılavuzdur" sözüyle tarihin, bireylerin dolayısıyla toplumların bilinçlenmesindeki rolünü ortaya koymaktadır. $\mathrm{Bu}$ nedenle; çevresiyle birlikte yaşamak durumunda olan insanın, sağlıklı bir hayat veya düşünce tarzına sahip olabilmesi için önce kendini, sonra mensubu olduğu toplumu tanıması gerekir.

Geçmişi yorumlamak da, geleceği biçimlendirmek de, ancak tarih bilinciyle olanaklıdır. Tarih bilinci, insanın hem geçmişi yorumlamasında, hem degeleceğikurmasında, ona yön vermesinde rol oynamaktadır. Tarihi, kendi değerleri, amaçları ve eylemleriyle kurduğunun bilincine varan insan, geleceği de kendi idealleri ve beklentileri yönünde aynı bilinçle belirlemek ister. Bu amaçla insanlığın bir parçası olduğu bilincini taşıyarak, ülkesini ve dünyayı ilgilendiren konulara duyarlılık gösteren ve etkili vatandaşlık bilincine ulaşmış insan modeli oluşturmada kullanılan Sosyal Bilgiler, bireyin incelenmesi, onun sosyal ve fiziki çevresiyle etkileşimi ve bu etkileşimin dünkü, bugünkü ve yarınki şekillerinin gözden geçirilmesini sağlar. $O$ halde Sosyal Bilgiler öğretim programlarında ve ders kitaplarında yer alan tarih konuları, bireyde tarih bilinci oluşturulmasına yardımcı olacak nitelikte olmalıdır. 


\section{KAYNAKÇA}

Akyüz, Y. (2001). Türk Eğitim Tarihi, İstanbul, Alfa Yayınları.

Bıçak, A. (1996). Tarih Bilinci, İstanbul, Sayı:20/46-58, Felsefe Dünyası.

Biçer, B. (2008). Tarihe Giriş, İstanbul, Dem Yayınları.

Davutoğlu, A. (2011). Stratejik Derinlik, İstanbul, Küre Yayınları.

Doğanay, A. (2008). Çağdaş Sosyal Bilgiler Anlayışı Işığında Yeni Sosyal Bilgiler Programının Değerlendirilmesi, Cilt:17-2/ 77-96, Adana, Çukurova Üniversitesi Sosyal Bilimler Enstitüsü Dergisi.

Fazlıoğlu, İ. (2009). Türkiye'de Türkçede Felsefe Üzerine Konuşmalar, İstanbul, Küre Yayınları.

Işık, H. (2008). Tarih Öğretiminde Doküman Kullanımının Öğrencilerin Tarihsel Düşünme Becerilerine ve Başarılarına Etkisi, (Yayınlanmamış Doktora Tezi), Ankara, Gazi Üniversitesi Yayınları.

Köseoğlu, N. (2005). Türk Olmak Ya da Olmamak, İstanbul, Ötüken Yayınları.

Köstüklü, N. (1998). Sosyal Bilimler ve Tarih Öğretimi, Konya, Kuzucular Ofset.

Memiş, E. (1998). Türk Kültür Tarihi, Konya, Çizgi Kitabevi Yayınları.

Niyazi, M. (2009). Türk Tarih Felsefesi, İstanbul, Ötüken Yayınları.

Özlem, D. Ateşoğlu, G. (2006). Tarih Felsefesi Seçme Metinler, Ankara, Doğu Batı Yayınları.

Öztürk, C. (2009). Sosyal Bilgiler Öğretimi, Ankara, Pegem Akademi Yayınları.

Öztürk, M. (2010). Tarih Felsefesi, Ankara, Kültür Bakanlığı Yayıncılık.

Polat, F. (2006). İlköğretim 7. Sınıf Sosyal Bilgiler Öğretiminde Öğretmenlerin Kullandıkları Yöntemler ve Karşılaştıkları Sorunlar-Afyon İli Örneği, (Yayınlanmamış Yüksek Lisans Tezi), Ankara, Gazi Üniversitesi Yayınları.

Sander, O. (2010). Siyasi Tarih İlkçağdan 1918'e, Ankara, İmge Kitabevi. 